\title{
A Rare Cause of Hemoptysis: Goodpasture Syndrome
}

\author{
Nadir Bir Hemoptizi Nedeni: Goodpasture Sendromu
}

Mehmet Ünlü, Pınar Çimen, İsmail Kayaalp, Nuran Katgı, Salih Zeki Güçlü

\section{Abstract}

Goodpasture syndrome is a rare, autoimmune disease characterized by diffuse pulmonary hemorrhage $(\mathrm{DAH})$, glomerulonephritis, and the production of anti-glomerular basement membrane antibodies. A 20-year-old male presented to the emergency department of our hospital with progressive dyspnea and intermittent hemoptysis over the last four months. His posteroanterior chest radiograph demonstrated reticulonodular opacities throughout the both lungs and alveolar hemorrhage was the dominant pathologic finding of the transbronchial biopsies. The urinalysis revealed microscopic hematuria and microalbuminuria, and the percutaneous kidney biopsy demonstrated crescentic glomerulonephritis. Antiglomerular basement membrane antibodies were detected in the circulation and the patient was diagnosed with Goodpasture syndrome. This syndrome usually starts with DAH, which is followed by symptoms of kidney disease and may result in chronic kidney failure. Physicians should always keep this syndrome in mind, especially in young adults presenting with $\mathrm{DAH}$; treatment of this syndrome should be initiated as soon as possible.

Key words: Diffuse alveolar hemorrhage, Goodpasture syndrome, crescentic glomerulonephritis.

\section{Özet}

Goodpasture Sendromu nadir görülen ve otoimmün kökenli bir hastalık olup diffüz alveoler hemoraji (DAH), glomerülonefrit ve anti-glomerüler bazal membran antikorlarının üretimi ile karakterizedir. Yirmi yaşında erkek hasta hastanemizin acil servisine dört aydan beri artış gösteren nefes darlığı ve tekrarlayan hemoptizi yakınmaları ile başvurdu. Hastanın posteroanterior akciğer grafisinde her iki akciğerin tüm zonlarında retikülonodüler opasite artışı ve transbronşial akciğer biyopsisinde alveoler hemoraji ile uyumlu bulgular saptand. İdrar analizinde hematüri ve mikroalbüminüri tespit edilen hastanın, böbrek biyopsisi sonucu da kresentik glomerülonefrit olarak raporlandı. Dolaşımda antiglomerül bazal membran antikorlarının varlığı tespit edildi ve hastaya Goodpasture Sendromu tanısı konuldu. Goodpasture Sendromunda ilk başvuru genellikle DAH şeklinde olmakla birlikte, kronik böbrek yetmezliğine neden olabilecek böbrek tutulumu da gelişebilmektedir. Özellikle genç erişkinlerde DAH ile başvuran hastalarda bu tanı akla getirilmeli ve uygun tedavi en kısa süre içerisinde başlanmalıdır.

Anahtar Sözcükler: Diffüz alveoler hemoraji, Goodpasture sendromu, kresentik glomerülonefrit.

Correspondence (iletişim): Mehmet Ünlü, Department of Pulmonology, Dr. Suat Seren Training and Research Hospital for Thoracic Medicine and Surgery, İzmir, Turkey

e-mail: lidokain21@hotmail.com 
Diffuse alveolar hemorrhage (DAH) is a life-threatening disorder, which refers to bleeding that originates from the pulmonary microvasculature (1). DAH is considered a medical emergency due to the morbidity and mortality associated with failure to treat the disorder promptly, and is clinically characterized by the presence of hemoptysis, decrease in hematocrit levels, diffuse pulmonary infiltrates, and hypoxemic respiratory failure (2).

A variety of diseases are associated with the development of the DAH. From a diagnostic and therapeutic perspective, it can be useful to divide cases of DAH into two main groups: those associated with inflammation of the network of small pulmonary capillaries (capillaritis) and those not associated with capillaritis $(3,4)$ (Table 1).

Although the differential diagnosis is broad, the majority of cases of DAH are caused by a relatively small number of conditions. Goodpasture syndrome is an autoimmune disease that is classified among the diseases not associated with capillaritis (at times it can display focal capillaritis) and is a rare cause of DAH (5).

Herein, we report a successfully treated case of Goodpasture syndrome that presented with the typical clinical features of DAH.

Table 1: Classification of diffuse alveolar hemorrhage

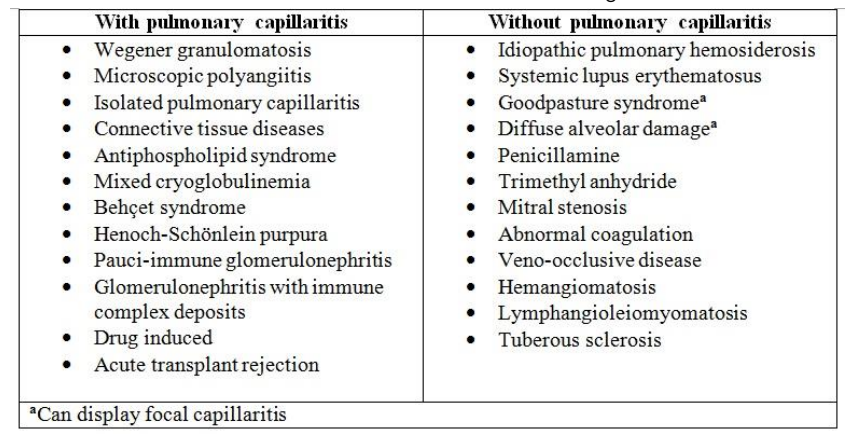

\section{CASE}

A 20-year-old male presented to the emergency department of our hospital with progressive chest pain, dyspnea, and intermittent hemoptysis affecting him particularly over the last four months. There was also a history of significant loss of weight and appetite. He had been studying at university for the past two years. His smoking history was four packs/year and there was no past history of a chronic disease. He had never consumed illicit drugs and had no allergies.

On admission, patient was in respiratory distress with a respiratory rate of 35 breaths/minute, blood pressure of $110 / 70 \mathrm{mmHg}$, and a heart rate of approximately 140 beats/minute with sinus tachycardia. Chest auscultation revealed the presence of fine bilateral crepitation in the lower zones of both lungs. An examination of the blood samples revealed leukocytosis $\left(17,700 / \mathrm{mm}^{3}\right)$, neutrophilia $\left(10,500 / \mathrm{mm}^{3}\right)$, and anemia (hemoglobin: $6.9 \mathrm{~g} / \mathrm{dl}$ ). The number of thrombocytes and results of blood chemistry were within normal limits. The erythrocyte sedimentation rate was $70 \mathrm{~mm} / \mathrm{h}$ and serum level of C-reactive protein was $1.5 \mathrm{mg} / \mathrm{dl}$. The laboratory results for the HIV test and serological screening for vasculitis [autoantibodies to deoxyribonucleic acid (DNA), double stranded DNA, proteinase-3 (c-ANCA), myeloperoxidase ( $p-A N C A)$, and rheumatoid factor] were negative. The measurement of arterial blood gas analysis on room air revealed the following: $\mathrm{pH}: 7.44, \mathrm{PaCO}_{2}: 36 \mathrm{mmHg}, \mathrm{PaO}_{2}: 44 \mathrm{mmHg}$, $\mathrm{HCO}_{3}: 27 \mathrm{mmol} / \mathrm{L}$, and $\mathrm{SaO}_{2}: 78 \%$ the values of which were compatible with hypoxemic respiratory failure. The serology test for cold agglutinins was negative.

The patient's chest radiograph demonstrated reticulonodular opacities throughout both lungs and a homogenous consolidation with air bronchograms especially in the lower zone of the left lung (Figure 1a). Computerized Tomography (CT) of the thorax demonstrated peribronchial thickening, patchy areas of ground-glass, and thickened interlobular septae in all zones of both lungs, which suggested an interstitial lung disease (Figure 2).

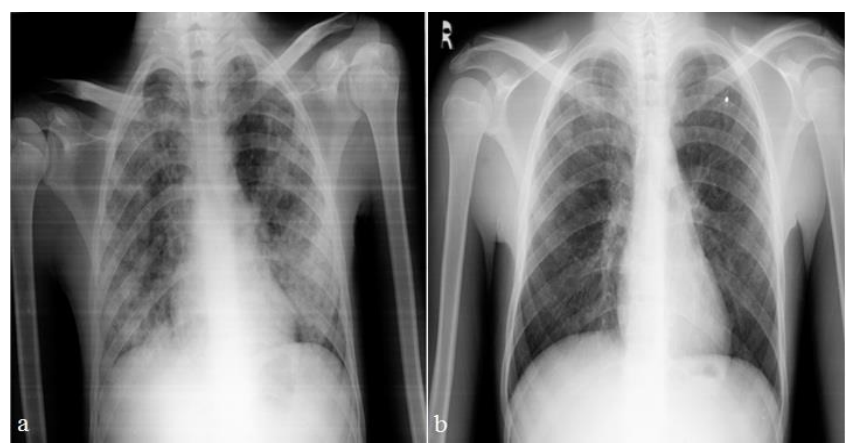

Figure 1a and b: Chest radiographs of the patient: (a) On admission (b) 2 weeks after initiation of the treatment

The patient was admitted to the intensive care unit due to the requirement of non-invasive mechanical ventilation. The following day, the requirement for ventilation support decreased and bronchoscopy with bronchoalveolar lavage (BAL) and transbronchial biopsies were performed. During the bronchoscopy procedure the bronchi appeared to be inflamed and contained increased secretions. Alveolar hemorrhage was the dominant pathologic finding of the transbronchial biopsies. There was also evidence of injury at the level of the alveolar wall, manifested by hyaline membranes and widening of alveolar walls by edematous connective tissue. BAL fluid showed hemorrhagic effluent with a large number of hemosiderin- 
containing histiocytes. Total cell count on BAL was 185 cells/mL with $79 \%$ macrophages, 12\% neutrophils, 5\% lymphocytes, and 4\% eosinophils. Gram stain and cultures of the bronchial washings and BAL fluid did not reveal any infectious organism. Special stains and cultures for mycobacteria, Pneumocystis jiroveci, fungi, and Legionella pneumophila were also negative.

The urinalysis revealed microscopic hematuria and microalbuminuria. He underwent a urinary tract ultrasound, which demonstrated a reduced size and increased echogenicity of both kidneys (grade 1), and an indistinct sinusparenchyma border. The enzyme-linked immunosorbent assay (ELISA) for anti-glomerular basement membrane antibodies (AGBMA) was positive and a percutaneous kidney biopsy demonstrated crescentic glomerulonephritis. Based on the clinical, radiological, and pathological findings, the patient was diagnosed with Goodpasture syndrome.

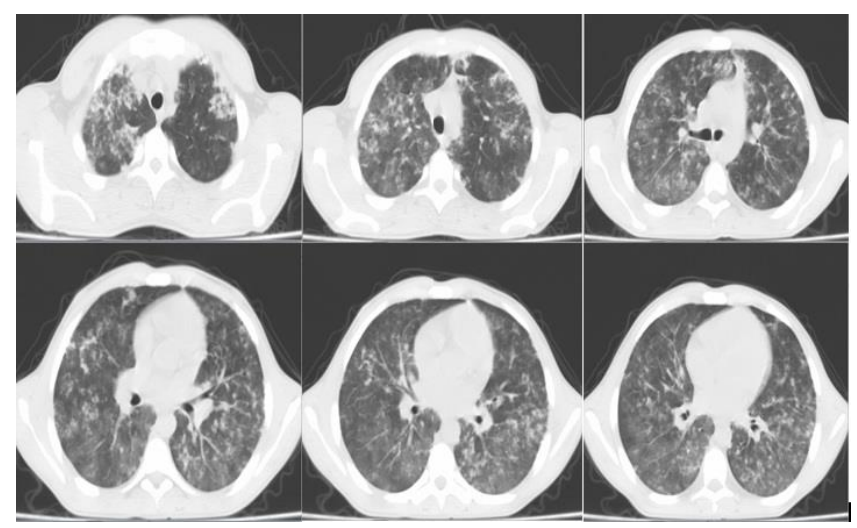

Figure 2: Thorax CT images of the patient on admission

The patient initially underwent plasmapheresis and treatment and a high dose intravenous corticosteroids (1000 $\mathrm{mg} /$ day for the first three days) was initiated. Then a dose of oral corticosteroid at $1 \mathrm{mg} / \mathrm{kg} /$ day of ideal body weight continued for two weeks, after which the dose is reduced every two weeks to $30 \mathrm{mg}$ by the eighth week. The dosages of corticosteroids were then tapered 5 $\mathrm{mg} / \mathrm{month}$ and discontinued at the sixth month of the treatment.

The chest radiograph of the patient cleared markedly within two weeks of the treatment (Figure 1b). He was discharged 30 days after admission. Follow-up examinations at one and four weeks after discharge revealed normal laboratory results and a normal chest radiograph. The pulmonary function tests two months after admission showed no ventilation defects. The last contact with the patient was a polyclinic visit for a check-up one year after discharge and he was free of all previous symptoms.

\section{DISCUSSION}

The disease was first described by the American pathologist Ernest Goodpasture in 1919 and was later named in his honor (6). The main characteristic of the disease is the presence of circulating AGBMA. Hence, the term "anti-glomerular basement membrane disease" is also used to determine this disease.

In this disease, AGBMA are directed against type IV collagen (especially NCl domain of the $\alpha-3$ chain), which is a major component of the alveolar and glomerular basement membranes (7). In Goodpasture syndrome, AGBMA are present in more than $90 \%$ of the patients and detection of AGBMA has an overall good sensitivity (95\%) and specificity (97\%) for the disease (8).

The etiology of this syndrome is still unknown and the main target organs involved in this disease are the lungs and kidneys. In addition, generalized symptoms such as malaise, weight loss, fatigue, fever and chills, and joint aches and pains are also common (9). Hemoptysis is generally observed in a mixed form with saliva and massive hemoptysis rarely occurs (10). Concomitant pulmonary and renal involvement occurs in up to $80 \%$ of the cases (9), whereas isolated glomerulonephritis occurs in most of the remaining cases (8). Sole DAH occurs in less than $10 \%$ of the cases $(9,11)$. The serum level of AGBMA is correlated with the severity of the renal involvement, but there is no relationship between antibody levels and pulmonary damage (12). In the study by Markowitz et al.(12), circulating AGBMA were detected less often and at lower levels in individuals with normal renal function than in those with impaired renal function. The main pathological pattern observed in the renal involvement of the Goodpasture syndrome is crescentic glomerulonephritis even in patients without clinical evidence of renal disease, which may lead to chronic renal insufficiency (13). AGBMA generally have the structure of immunoglobulin $G(\lg G)$ and immunofluorescence examination reveals a linear deposition of $\lg G$ along the basement membranes of the glomerular tufts and alveolar walls in majority of the cases (14). Although c-ANCA and p-ANCA positivities are rarely detected in some cases, these markers are not useful for the diagnosis of the disease (15). In this case, the diagnosis was based on the circulating AGBMA and presence of the crescentic glomerulonephritis. An immunofluorescence study could not be performed because of the lack of the stains in the laboratory. 
Goodpasture syndrome occurs more frequently in men. Although any age group may be affected, most patients are between 20 and 30 years of age (9). Histocompability human leucocyte antigen HLA-DRW2 is detected in a majority of the patients, suggesting a genetic susceptibility (16). Cigarette smoking has been associated with Goodpasture syndrome and restarting smoking is related to recurrent DAH (17). The patient in this case was also a male and had an active smoking history.

Treatment of the disease depends on extent of the involvement. The disease generally responds to corticosteroids alone, and in patients with only DAH and without renal involvement. However, renal involvement requires treatment with a combination of the corticosteroids, cytotoxic drugs (cyclophosphamide, azathioprine), and plasmapheresis according to severity of the case. After discharge from the hospital, patients require long-term regular visits to monitor renal function and immunosuppressive therapy. If renal function does not return, dialysis is continued indefinitely and the patient should be referred for renal transplantation (18). The serum level of AGBMA is a good predictor of the treatment success and decreases rapidly in majority of the cases in the first eight weeks of the treatment. Continuation of the treatment is recommended for the next three to six months after the disappearance of AGBMA in the serum $(19,20)$. This patient was treated with the combination of corticosteroids and plasmapheresis and luckily had no sign of kidney failure after one year of the treatment. There was no need to use cytotoxic drugs in this case. AGBMA negativity was detected at ten weeks of treatment and the treatment was terminated six months after disappearance of AGBMA. Among all the etiologies of DAH, Goodpasture syndrome has the poorest response to therapy and poorest survival, which is associated with early and undetected renal involvement (21). Progressive renal disease is a poor prognostic factor. Spontaneous regression has been reported to occur in cases without renal involvement (22). It is possible to mention that, not to have a serious renal involvement and early detection of micro-albuminuria were chances of this patient which protected him from kidney failure.

In conclusion, Goodpasture syndrome should always be kept in mind, especially in young patients presenting with DAH and proper treatment should be initiated in time to avoid irreversible kidney failure.

\section{CONFLICTS OF INTEREST}

None declared.

\section{AUTHOR CONTRIBUTIONS}

Concept - M.Ü., P.Ç., I.K., N.K., S.Z.G., T.V; Planning and Design - M.Ü., P.Ç., I.K., N.K., S.Z.G.; Supervision M.Ü., P.Ç., I.K., N.K., S.Z.G.; Funding - M.Ü., P.Ç., I.K., N.K., S.Z.G.; Materials - M.Ü., P.Ç., I.K., N.K., S.Z.G.; Data Collection and/or Processing - M.Ü., P.Ç., İ.K., N.K., S.Z.G.; Analysis and/or Interpretation - M.Ü., P.Ç., i.K., N.K., S.Z.G.; Literature Review - M.Ü., P.Ç., I.K., N.K., S.Z.G.; Writing - M.Ü.; Critical Review - M.Ü., P.Ç., i.K., N.K., S.Z.G.

\section{YAZAR KATKILARI}

Fikir - M.Ü., P.Ç., I.K., N.K., S.Z.G.; Tasarım ve Dizayn M.Ü., P.Ç., I.K., N.K., S.Z.G.; Denetleme - M.Ü., P.Ç., I.K., N.K., S.Z.G.; Kaynaklar - M.Ü., P.Ç., I.K., N.K., S.Z.G.; Malzemeler - M.Ü., P.Ç., I.K., N.K., S.Z.G.; Veri Toplama ve/veya isşleme - M.Ü., P.Ç., I.K., N.K., S.Z.G.; Analiz ve/veya Yorum - M.Ü., P.Ç., I.K., N.K., S.Z.G.; Literatür Taraması - M.Ü., P.Ç., I.K., N.K., S.Z.G.; Yazıyı Yazan - M.Ü.; Eleştirel İnceleme - M.Ü., P.Ç., i.K., N.K., S.Z.G.

\section{REFERENCES}

1. Albelda SM, Gefter WB, Epstein DM, Miller WT. Diffuse pulmonary hemorrhage: a review and classification. Radiology 1985; 154:289-97. [CrossRef]

2. Collard HR, Schwarz MI. Diffuse alveolar hemorrhage. Clin Chest Med 2004; 25:583-92. [CrossRef]

3. Green RJ, Ruoss SJ, Kraft SA, Duncan SR, Berry GJ, Raffin TA. Pulmonary capillaritis and alveolar hemorrhage. Update on diagnosis and management. Chest 1996; 110:1305-16.

4. Schwarz MI, Brown KK. Small vessel vasculitis of the lung. Thorax 2000; 55:502-10.

5. Oymak FS, Tokgoz B, Akgun H, Gulmez I, Erdogan N, Demir R, et al. Alveolar hemorrhage syndromes; clinical, pathological and imaging features: analysis of eleven patients. Turkish Thorac J 2002; 3:52- 8 .

6. Salama AD, Levy JB, Lightstone L, Pusey CD. Goodpasture's disease. Lancet 2001; 358:917-20. [CrossRef]

7. Meyers KE, Allen J, Gehret J, Jacobovits A, Gallo M, Neilson EG, et al. Human antiglomerular basement membrane autoantibody disease in XenoMouse II. Kidney Int 2002; 61:1666-73.

8. Jaskowski TD, Martins TB, Litwin CM, Hill HR. Comparison of four enzyme immunoassays for the detection of immunoglobulin $G$ antibody against glomerular base- 
ment membrane. J Clin Lab Anal 2002; 16:143-5. [CrossRef]

9. Kathuria P, Sanghera P, Stevenson FT, Sharma S, Lederer E, Lohr JW, et al. Goodpasture syndrome clinical presentation. Access date: 21 May 2013. Place of access: http://emedicine.medscape.com/article/240556-clinical.

10. Uğurman F, Gözü A. Alveolar hemoraji sendromları. In: Erdoğan Y, Samurkaşoğlu B (eds): Diffüz parankimal akciğer hastalıkları. Ankara: Mesut Matbaacılık, 2004: 305- 28.

11. Leatherman JW, Davies SF, Hoidal JR. Alveolar hemorrhage syndromes: diffuse microvascular lung hemorrhage in immune and idiopathic disorders. Medicine (Baltimore) $1984 ; 63: 343-61$.

12. Markowitz GS, Radhakrishnan J, D'Agati VD. An overlapping etiology of rapidly progressive glomerulonephritis. Am J Kidney Dis 2004; 43:388-93. [CrossRef]

13. Jennette JC, Thomas DB. Crescentic glomerulonephritis. Nephrol Dial Transplant 2001; 16 (Suppl 6):80-2. [CrossRef]

14. Travis WD, Koss MN, Ferrans VJ. The lung in connective tissue disorders. In: Haselton PS (ed): Spencer's Pathology of the Lung. New York: McGraw-Hill, 1996: 803-34.

15. Dammacco F, Battaglia S, Gesualdo L, Racanelli V. Goodpasture's disease: a report of ten cases and a review of the literature. Autoimmun Rev 2013; 12:1101-8. [CrossRef]
16. Rees AJ, Peters DK, Compston DA, Batchelor JR. Strong association between HLA-DRW2 and antibody-mediated Goodpasture's syndrome. Lancet 1978; 1:966-8. [CrossRef]

17. Jones JG, Minty BD, Lawler P, Hulands G, Crawley JC, Veall N. Increased alveolar epithelial permeability in cigarette smokers. Lancet 1980; 1:66-8. [CrossRef]

18. Hirayama K, Yamagata K. The anti-GBM disease: treatments and outcomes. OA Nephrology 2013; $1: 1$. [CrossRef]

19. Fraser RS, Müller NL, Colman N, Pare PD. Goodpasture's Syndrome and idiopathic pulmonary hemorrhage. In: Fraser RS, Müller NL, Colman N, Pare PD (eds): Diagnosis of Diseases of the Chest, 4th. Philadelphia: WB Saunders Company; 1999: 1757-69.

20. Levy JB, Lachmann RH, Pusey CD. Recurrent Goodpasture's disease. Am J Kidney Dis 1996; 27:573-8.

21. Fontenot AP, Schwarz MI. Diffuse alveolar hemorrhage. In: Schwarz MI, King TE (eds): Interstitial Lung Disease. Ontario: BC Decker; 2003: 632-56.

22. Seaton A, Meland JM, Lapp NL. Remission in Goodpasture's syndrome: report of two patients treated by immunosuppression and review of the literature. Thorax 1971; 26:683-8. [CrossRef] 